\title{
Removal of Methylene Blue Dye from Aqueous Solutions by Bentonite and Cement Kiln Dust: Comparative Study of Adsorption Equilibrium, Kinetic, and Thermodynamic
}

\author{
Ahmed A. El-Refaey
}

\begin{abstract}
This study compared the methylene blue (MB) removal from aqueous solution by natural bentonite (Bent) and cement kiln dust (CKD). Bentonite and CKD were characterized by X-ray diffraction (XRD), X-ray fluorescence (XRF), Brunauer Emmett Teller (BET) specific surface area, Fourier transform infrared (FTIR), and scanning electron microscopy (SEM). The comparison between bentonite and CKD in the removal of MB dye was investigated in different conditions including initial $\mathrm{MB}$ concentration, adsorbent doses, $\mathrm{pH}$, salt concentration, and temperature by batch experiments. Adsorption kinetics results were fitted with fractional power, Elovich, pseudofirst-order, pseudo-second-order, and intra-particle diffusion equations. The pseudo-second-order model was well fitted for experimental results at the different tested initial concentrations (50-300 $\mathrm{mgMB} / \mathrm{L})$. Equilibrium adsorption data were evaluated by Freundlich and Langmuir and Temkin models. The experimental results fitted very well by the Langmuir isotherm model. Bentonite exhibited the largest adsorption capacity (3257.33 $\mathrm{mg} / \mathrm{g})$ than CKD (2150.54 $\mathrm{mg} / \mathrm{g})$. Increasing the temperature from $298 \mathrm{~K}$ to $323{ }^{\circ} \mathrm{K}$ convinced an increase of the adsorption of MB dye by both sorbents and the process was found to be endothermic and spontaneous. The obtained results indicated that both adsorbents are efficient and low-cost adsorbents for effective removal of MB dye with privilege in the efficiency for bentonite and with no cost for CKD.
\end{abstract}

Keywords: Bentonite; Cement Kiln Dust; methylene blue; kinetic and adsorption isotherm; Thermodynamic.

\section{INTRODUCTION}

Dyes are one of the serious aquatic environmental threaten. More than 100,000 dyes used in several industries such as textile, leathers, paint, paper, plastics, food, cosmetics, pharmaceutica, etc (Sen et al., 2011; Djelloul and Hamdaoui, 2014). Textile industries use more than $70 \%$ of the total produced dyes all over the world (Chudgar et al., 2014). Annually, these industries used a huge amount of water and about 5,000-10,000 tons of dyes which are released as effluent into the waterways (Pirkarami and Olya, 2017; Yagub et al., 2014).

Most dyes are toxic to human beings and can cause allergy to skin, and act as mutagenic and carcinogenic agents (Khan and Malik, 2018; Lellis et al., 2019). Also can threaten aquatic organisms and can be resistant to natural biological degradation. Moreover, the presence of dyes in water bodies can decrease the transparency and light penetration through the water, related to the color, that influence photosynthesis then consequently reduces dissolved oxygen levels which affect aquatic biota (Sun et al., 2008; Hameed, 2009; Imran et al., 2015; Hassan and Carr, 2018). According to the molecule's ionic charge, dyes classified as anionic, cationic, and non-ionic. Methylene blue (MB) is a cationic dye that has numerous uses, includes dyeing cotton, wools, coating for paper stock, etc (Vargas et al., 2012; Fayoud et al., 2016). It can cause harmful effects to humans and animals such as eye burns, nausea, diarrhea, besides the negative effect on photosynthesis (EI-Latif et al. 2010; Bulgariu et al., 2019). Therefore, the removal of such dyes from waste effluent is very important for the aquatic environment.

Numerous treatment techniques such as adsorption, ion exchange, reverse osmosis, biodegradation, coagulation-flocculation, electrochemical oxidation, fenton oxidation, and ozonation are applied to remove dyes from wastewater effluents (Pai et al., 2021). Adsorption is still the most efficient and cost-effective method for dye removal from waste effluent (Hassan and Carr, 2018).

Most of the recent dye removal studies have concentrated on the developing of locally low-cost agricultural and domestic waste materials or industrial by-products (Bello et al., 2015; Kadhom et al., 2020; Wong et al., 2020). For its availability in nature, clay minerals or its modifications, by calcination, treated with acid, salt exchange, and organification, have been used as effective sustainable and low-cost materials for the dyes removal from aqueous solution (El Mouzdahir

DOI: 10.21608/asejaiqjsae.2021.186823

*Department of Soil \& Water Science,

Faculty of Desert and Environmental Agriculture,

Matrouh University, Egypt; E-Mails: ahmedelrefaey@alexu.edu.eg

Received June 10, 2021, Accepted, July 29, 2021. 
et al., 2010; Pentrák et al., 2012; Liu et al, 2014; Medria et al., 2020). The variance in the dye adsorption capacity between different clay minerals is related to their surface properties and chemical structure. Bentonite, primarily smectite clay, has been successfully applied for adsorption of dyes for possessing permanent negative charges and exchangeable cations, its saltresistance, and low hydration rate (Tahir and Rauf, 2006; Hong et al., 2009; Liu et al, 2014; Anirudhan and Ramachandran, 2015). Otherwise, cement kiln dust (CKD) is created in the cement manufacturing process as a by-product. Because of its physicochemical properties, CKD has reported as effective in removing heavy metals ions (Salem et al., 2015, El-Refaey, 2016 and 2017; El-Refaey and Mohammad, 2019) and dyes (Magdy and Altaher, 2018).

The aim of this study was to compare bentonite as a clay mineral and cement kiln dust as an industrial byproduct for methylene blue dye removal from aqueous solutions. Bentonite and cement kiln dust characterization were compared. Moreover, their surface morphology and infrared Fourier transform (FTIR) were inspected before and after the experiment with MB dye adsorption. Batch experiments were conducted for evaluating the impact of different conditions, such as contact time, $\mathrm{pH}$ solution, adsorbent dosage, initial dye concentration, and temperature on MB dye removal. Kinetic studies were examined by pseudo-first-order, pseudo-second-order, and Elovich models, while the equilibrium results were examined by Langmuir and, Freundlich isotherm models. Finally, to assess the feasibility and spontaneity of the removal reactions, thermodynamic parameters were determined.

\section{MATERIALS AND METHODS}

\section{Adsorbate}

The methylene blue (MB) is a basic dye has strong ability for adsorption onto solids. The Chemical structure of $\mathrm{MB}$ is $\mathrm{C}_{16} \mathrm{H}_{18} \mathrm{Cl} \mathrm{N} \mathrm{N}_{3} \mathrm{~S}$ (Fig. 1), and the maximum wavelength ( $\lambda$ max) is $665 \mathrm{~nm}$ (Merck, German). One gram of MB dye was dissolved in 1000 $\mathrm{mL}$ distilled water to make a stock solution of 1000 $\mathrm{mg} / \mathrm{L}$. The different concentration solutions used in this study were $50,100,200$, and $300 \mathrm{mg} / \mathrm{L}$ as prepared by dilution using distilled water.<smiles>CN(C)c1ccc2nc3ccc(N(C)C)cc3[s+]c2c1</smiles>

Fig.1. Chemical structure of methylene blue dye.

\section{Adsorbents characterization}

Two adsorbent materials were used in this study. (i) Bentonite (Bent) obtained from Egypt Company for Mining and Drilling Chemicals, (ii) cement kiln dust (CKD) collected from the El-Amerya cement plant, Alexandria, Egypt. Bentonite and CKD samples were sieved to ensure that the particle size range is less than $0.5 \mathrm{~mm}$ and then stored in plastic bottles for experimental uses.

X-ray diffraction (XRD) was conducted for bentonite and CKD by X-ray Powder Diffraction -XRDD2 Phaser Bruker (Germany) using the $\mathrm{Cu} \mathrm{K} \alpha$ radiation $((\lambda=1.541 \AA)$ at $30 \mathrm{kV}$ and $10 \mathrm{~mA}$. The diffractogram was scanned from $(2 \theta) 5$ to $45^{\circ}$.

The elemental chemical composition of bentonite and CKD was identified by X-ray fluorescence spectroscopy (XRF) using Axios advanced sequential wavelength dispersive X-ray fluorescence Spectrometer (Malvern Panalytica) (Table.1).

The specific surface area of bentonite and CKD was estimated using Brunauer-Emmett-Teller (BET) method from $\mathrm{N}_{2}$-adsorption isotherms using a gas adsorption analyzer (Beckman Coulter SA(TM) 3100). The Barrett-Joyner-Halenda (BJH) method from the $\mathrm{N}_{2}$ desorption isotherms was conducted for estimation of the pore size distribution (Nader, 2015).

Fourier transform-infrared (FTIR) spectra were determined at the range $400-4,000 \mathrm{~cm}^{-1}$ by a Fourier transform infrared spectrometer (Infra-Red Bruker Tensor 37, German) using the $\mathrm{KBr}$ pellet method. FTIR spectra were conducted before and after $\mathrm{MB}$ dye adsorption experiments by the two sorbents.

The surface morphology of bentonite and CKD were performed by a Jeol IT-200 scanning electron microscope. Before the examination, samples provided with a thin layer of gold in the sputter-coating unit (JFC1100E). Scanning electron microscopy (SEM) images were obtained at various magnification scales before and after adsorption experiments.

\section{Adsorption experiments and analytical methods}

Batch studies were conducted to study the influence of two adsorbents (Bent and CKD) on the removal of MB dye from aqueous solutions under different conditions. These conditions included: adsorbent doses $(0.05,0.1,0.2,0.4,0.6$, and $1 \mathrm{~g})$; pre-adjusted $\mathrm{pH}$ values (4, 6, 8, 10, and 12); initial MB concentrations (50, 100, $200,300 \mathrm{mg} / \mathrm{L}) ; \mathrm{NaCl}$ concentrations (0.05, 0.1, 0.2, $0.3,0.4$ and $0.5 \mathrm{~g})$; and different temperatures $(25,35$, and $45^{\circ} \mathrm{C}$ ). The $\mathrm{pH}$ values were adjusted using $1 \mathrm{M}$ $\mathrm{NaOH}$ or $0.1 \mathrm{M} \mathrm{HCl}$. For $\mathrm{pH}, \mathrm{NaCl}$ concentrations, and various temperatures conditions, a $0.20 \mathrm{~g}$ of adsorbent was added to $40 \mathrm{ml}(100 \mathrm{mg} \mathrm{MB} / \mathrm{L})$ in $50 \mathrm{~mL}$ plastic 
centrifuge tubes, and agitation was carried out for $4 \mathrm{~h}$ which is sufficient. The supernatants were chemically analyzed for the determination of the residual $\mathrm{MB}$ concentration at the end of the equilibrium period. All of the experiments were replicated.

For Kinetic and isotherms studies, a $1.00 \mathrm{~g}$ of sorbent was added to $250 \mathrm{~mL}$ glass Erlenmeyer flasks containing $200 \mathrm{~mL}$ of $\mathrm{MB}$ dye solution with various primary concentrations $(50-300 \mathrm{mg} / \mathrm{L})$ that were subjected to stirring at $130 \mathrm{rpm}$ for $360 \mathrm{~min}$ at $25^{\circ} \mathrm{C}$ to reach equilibrium. Samples of the mixture solution were withdrawn at various intervals time, centrifuged and analyzed for MB dye concentration.

Standard concentrations of MB dye solution with the yield absorbance were obtained at $665 \mathrm{~nm}$ wavelength by using UV-VIS double beam JENWAY 140 spectrophotometer model 6850 for obtaining the calibration curve. The concentration of $\mathrm{MB}$ dye was determined in the supernatant after centrifuged (for 5 $\min$ at $5000 \mathrm{rpm}$ ) and measured for residual MB dye concentration. The adsorption amount (qt) and the removal percentage of $\mathrm{MB}(\mathrm{R} \%)$ are calculated by the following equations:

$\mathrm{q}_{\mathrm{t}}=\left(\mathrm{c}_{\mathrm{o}}-\mathrm{c}_{\mathrm{t}}\right) \mathrm{V} / \mathrm{m}$

$\mathrm{R} \%=\left(\mathrm{c}_{\mathrm{o}}-\mathrm{c}_{\mathrm{t}}\right) / \mathrm{c}_{\mathrm{t}} \times 100$
Where; $q_{t}$ equals the amount of $M B$ dye adsorbed amount at time $\mathrm{t}(\mathrm{mg} / \mathrm{g}), \mathrm{R}$ equals the removal percentage $(\%), \mathrm{m}$ is the CKD sample weight $(\mathrm{g}), \mathrm{V}$ is the solution volume $\left(\mathrm{dm}^{3}\right)$, and $\mathrm{c}_{0}$ and $\mathrm{c}_{\mathrm{e}}$ equal the initial and equilibrium concentrations of MB dye, respectively.

\section{RESULTS AND DISCUSSION}

\section{Adsorbents Characterization}

\section{$\mathrm{X}$-ray diffraction and fluorescence analysis}

The XRD diffractograms of bentonite and CKD are presented in Fig. (2). The XRD pattern indicated that montmorillonite is the main dominant mineral for natural bentonite. The XRD pattern also indicated the presence of quartz, dolomite, and calcite as impurities. Obviously, Calcite was the main mineral in CKD composition with miners of dolomite, feldspars, and quartz (Fig. 2).

The main compositions of bentonite and CKD as identified by X-ray fluorescence spectroscopy (XRF) are presented in Table (1). The oxides: $\mathrm{SiO}_{2}(49.17 \%)$ and $\mathrm{Al}_{2} \mathrm{O}_{3}$ (14.55\%) in bentonite are the main compositions with association other oxides present such as $\mathrm{Fe}_{2} \mathrm{O}_{3}$ and, $\mathrm{MgO}$ which their percentages were higher than those of the CKD contents (Table 1).

Table 1. The main chemical constituents of bentonite (Bent) and cement kiln dust (CKD).

\begin{tabular}{|c|c|c|c|c|c|c|c|c|c|c|}
\hline & \multicolumn{9}{|c|}{ Main Constituents (wt \%) } & \multirow[b]{2}{*}{ LOI* } \\
\hline & $\mathrm{SiO}_{2}$ & $\mathrm{Al}_{2} \mathrm{O}_{3}$ & $\mathrm{Fe}_{2} \mathrm{O}_{3}$ & MgO & $\mathrm{CaO}$ & $\mathrm{Na}_{2} \mathrm{O}$ & $\mathbf{K}_{2} \mathbf{O}$ & $\mathrm{SO}_{3}$ & Cl & \\
\hline Bent & 49.17 & 14.55 & 7.37 & 2.23 & 0.75 & 3.25 & 0.68 & 0.31 & 0.85 & 17.96 \\
\hline CKD & 11.10 & 3.08 & 2.07 & 1.82 & 43.42 & 4.93 & 1.41 & 10.99 & 2.63 & 37.4 \\
\hline
\end{tabular}

*Loss on ignition

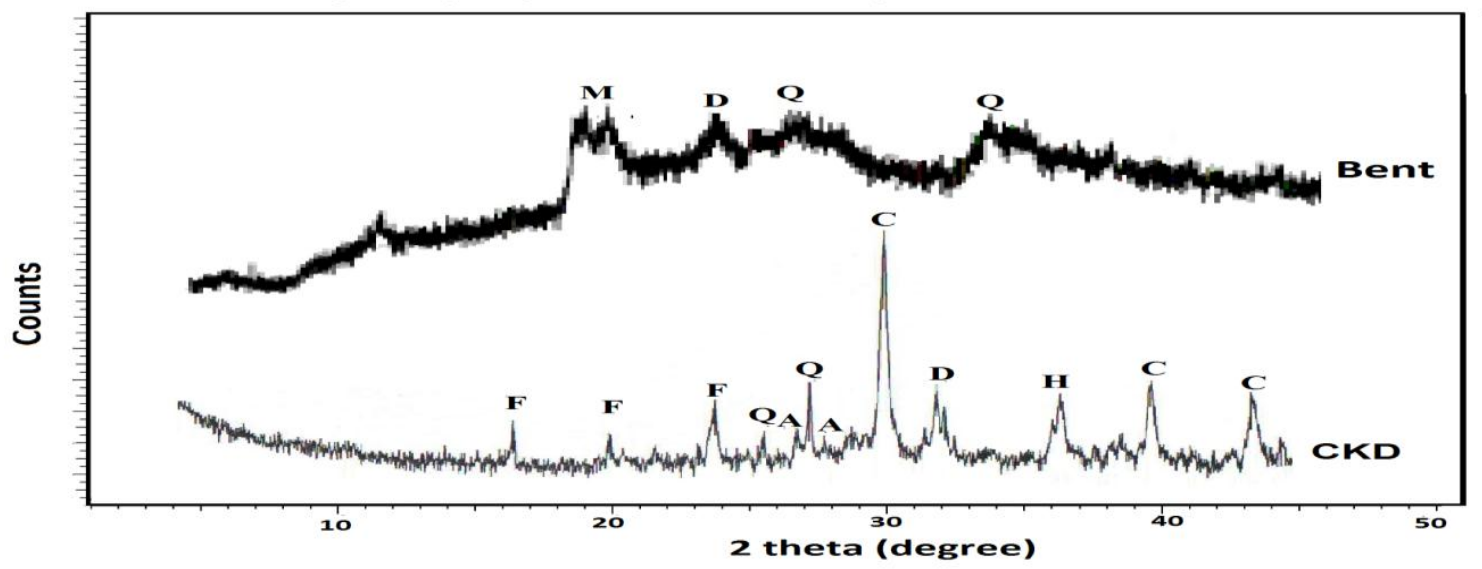

Fig.2. X-ray diffraction pattern of bentonite (Bent) and cement kiln dust (CKD).

(A: Anhydrite; C: Calcite, D: Dolomite; F: Feldspars; M: Montmorillonite; Q: Quartz). 
These constituents are accountable for the removal of MB dye (Tahir and Rauf, 2006). On the other hand, $\mathrm{CaO}(43.42 \%)$ is the main component of CKD with some alkali oxides (sodium and potassium) as reported in many studies (El-Refaey, 2016; El-Refaey, 2017). Also, the percentages of $\mathrm{SO}_{3}$ and $\mathrm{Cl}$ in $\mathrm{CKD}$ were higher than in those of bentonite. The adsorption characteristics of CKD can be attributed to both the high content of $\mathrm{CaO}$ and a significant percentage of $\mathrm{SO}_{3}$ (Miller and Azad, 2000; Magdy and Altaher, 2018).

\section{Specific surface area and pore analysis}

The specific surface area for bentonite and CKD was determined by the common $\mathrm{N}_{2}$-BET method at $77 \pm 1^{\circ}$ $\mathrm{K}$. Figure (3) showed the increase of the volume of adsorbed $\mathrm{N}_{2}$ with the rising of relative pressures (P/Po) for bentonite than CKD. Therefore, the estimated specific surface area of bentonite and CKD were 44.78 and $20.98 \mathrm{~m}^{2} \mathrm{~g}^{-1}$, respectively.

The desorption $\mathrm{BJH}$ pore size distribution for bentonite and CKD are listed in Table (2). Most of the pore diameter ranges fall within the range of mesoporous and microporous structures for both adsorbents. In addition, the pore diameter $<6 \mathrm{~nm}$, which is related to micropores, was the highest percentage in comparison with to the rest ranges, and bentonite has a higher percentage $(49.59 \%)$ than CKD (37.67\%). Thus, about $50 \%$ of the BJH pore diameter in bentonite relates to micropores and that may be reflected in the adsorption capacity. Also, the total pore volume of bentonite $\left(61.70 \mathrm{~mm}^{3} \mathrm{~g}^{-1}\right)$ was higher than CKD $(37.30$ $\mathrm{mm}^{3} \mathrm{~g}^{-1}$ ) (Table 2). CKD characterization depends upon the chemical composition of raw materials, the plant configuration, and the preprocessing type (Rahman et al., 2011; El-Refaey and Mohammad).

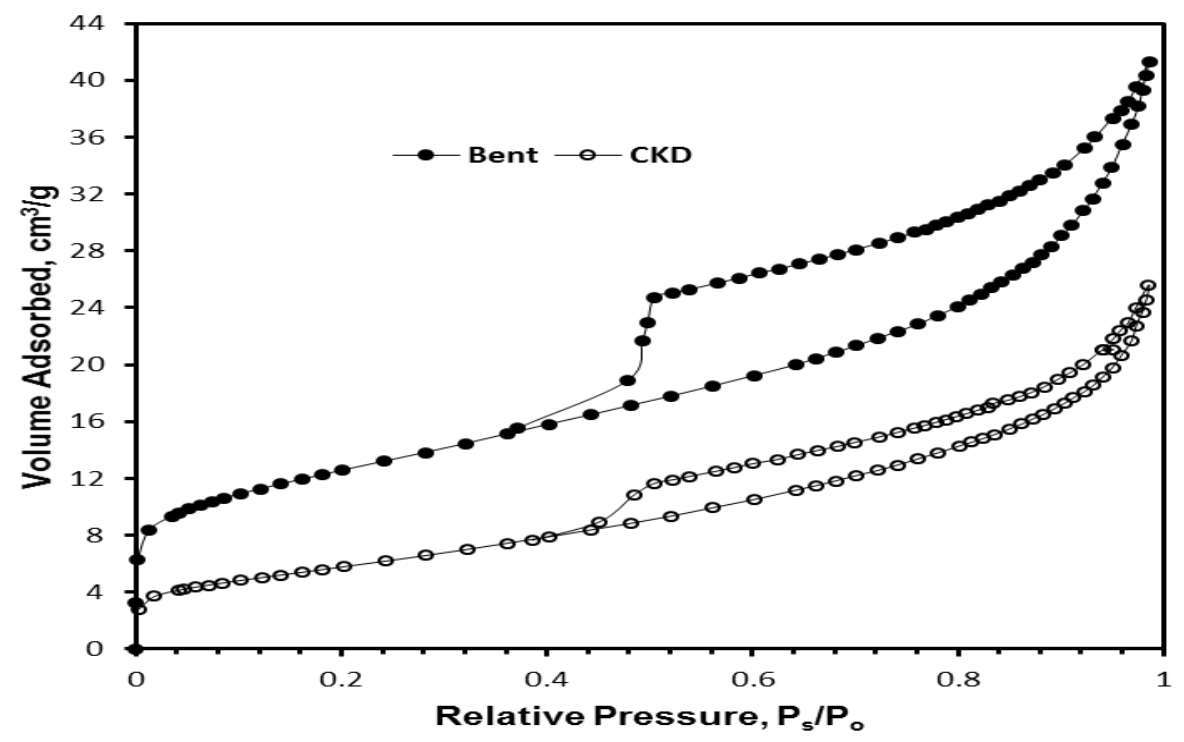

Fig. 3. $\mathrm{N}_{2}$-adsorption isotherms of bentonite (Bent) and cement kiln dust(CKD).

Table 2. Desorption Barrett-Joyner-Halenda (BJH) pore size distribution for bentonite (Bent) and cement kiln dust (CKD).

\begin{tabular}{|c|c|c|c|c|}
\hline \multirow{3}{*}{$\begin{array}{l}\text { Pore diameter range } \\
\text { nm }\end{array}$} & \multicolumn{4}{|c|}{ Pore volume } \\
\hline & \multicolumn{2}{|c|}{ Bent } & \multicolumn{2}{|c|}{ CKD } \\
\hline & $\mathrm{ml} \mathrm{g}^{-1}$ & $\%$ & ${\mathrm{ml} \mathrm{g}^{-1}}^{1}$ & $\%$ \\
\hline$<6$ & 0.0263 & 49.59 & 0.0136 & 37.67 \\
\hline $6-8$ & 0.0033 & 6.22 & 0.0028 & 7.68 \\
\hline $8-10$ & 0.0019 & 3.62 & 0.0019 & 4.40 \\
\hline $10-12$ & 0.0023 & 4.41 & 0.0020 & 4.74 \\
\hline $12-16$ & 0.0025 & 4.67 & 0.0018 & 5.07 \\
\hline $16-20$ & 0.0027 & 5.15 & 0.0022 & 6.02 \\
\hline $20-80$ & 0.0110 & 20.78 & 0.0096 & 26.55 \\
\hline$>80$ & 0.0030 & 5.56 & 0.0028 & 7.88 \\
\hline
\end{tabular}




\section{FTIR analysis}

FTIR spectra of the bentonite, as well as CKD, were conducted before and after the adsorption of MB dye from aqueous solutions including the bands corresponding to stretching and bending vibrations (Fig. 4). The bands at $3623.63 \mathrm{~cm}^{-1}$ and $916.36 \mathrm{~cm}^{-1}$ confirmed the presence of dioctahedral Smectite mineral with Al-OH-Al (Toor et al., 2015; Kumararaja et al., 2017). The band at $3695.61 \mathrm{~cm}^{-1}$ is assigned to Al-Mg$\mathrm{OH}$ stretching and $\mathrm{Al}-\mathrm{Fe}-\mathrm{OH}$ bending vibration at $787.52 \mathrm{~cm}^{-1}$ was representative of the bentonite clays (Sikdar et al., 2008; Osman et al., 2017). Peaks position at $1032.23 \mathrm{~cm}^{-1}, 529.11 \mathrm{~cm}^{-1}$ and $465.85 \mathrm{~cm}^{-1}$ were attributed to the $\mathrm{Si}-\mathrm{O}$ stretching vibration of bentonite mineral (Paluszkiewicz et al., 2008; Benhouria et al., 2015; Kumararaja et al., 2017). The band at 1463.20 $\mathrm{cm}^{-1}$ was corresponded to C-H stretching (Pavia et al., 2009; Anirudhan and Ramachandran, 2015). The broad band's at 3421.38 and $1633.03 \mathrm{~cm}^{-1}$ ascribed to the stretching of $\mathrm{O}-\mathrm{H}$ stretching vibrations in the mineral (Toor et al., 2015; Shehata et al., 2016; Reddy T et al., 2017). On the other hand, CKD FTIR spectrum indicated the presence of carbonate $\left(\mathrm{CO}_{3}{ }^{2-}\right.$ group $)$ at $1424.60 \mathrm{~cm}^{-1}$ and $873.58 \mathrm{~cm}^{-1}$ (Salem and Velayi, 2012; El-Refaey, 2016 and 2017). Peaks position at 1133.04 $\mathrm{cm}^{-1}$ and $710.20 \mathrm{~cm}^{-1}$ attributed to silicate stretching vibration (Al-Ghouti, 2003; Saraya and Aboul-Fetouh, 2012). The bands at 2978.79 and $2872.79 \mathrm{~cm}^{-1}$ are attributed to C-H stretching in alkanes (Xue et al., 2007; Meziti and Boukerroui, 2012; Chinoune et al., 2016), but the wave number of $613.30 \mathrm{~cm}^{-1}$ is related to $\mathrm{K}-\mathrm{O}$ vibration (Salem et al., 2012; El-Refaey and Mohammad, 2019). The existence of shifts and disappearance of functional group peaks in bentonite and CKD bands, were detected in FTIR spectrum after the adsorption experiment, which confirm the bending of MB dye onto bentonite and CKD (Fig.4).

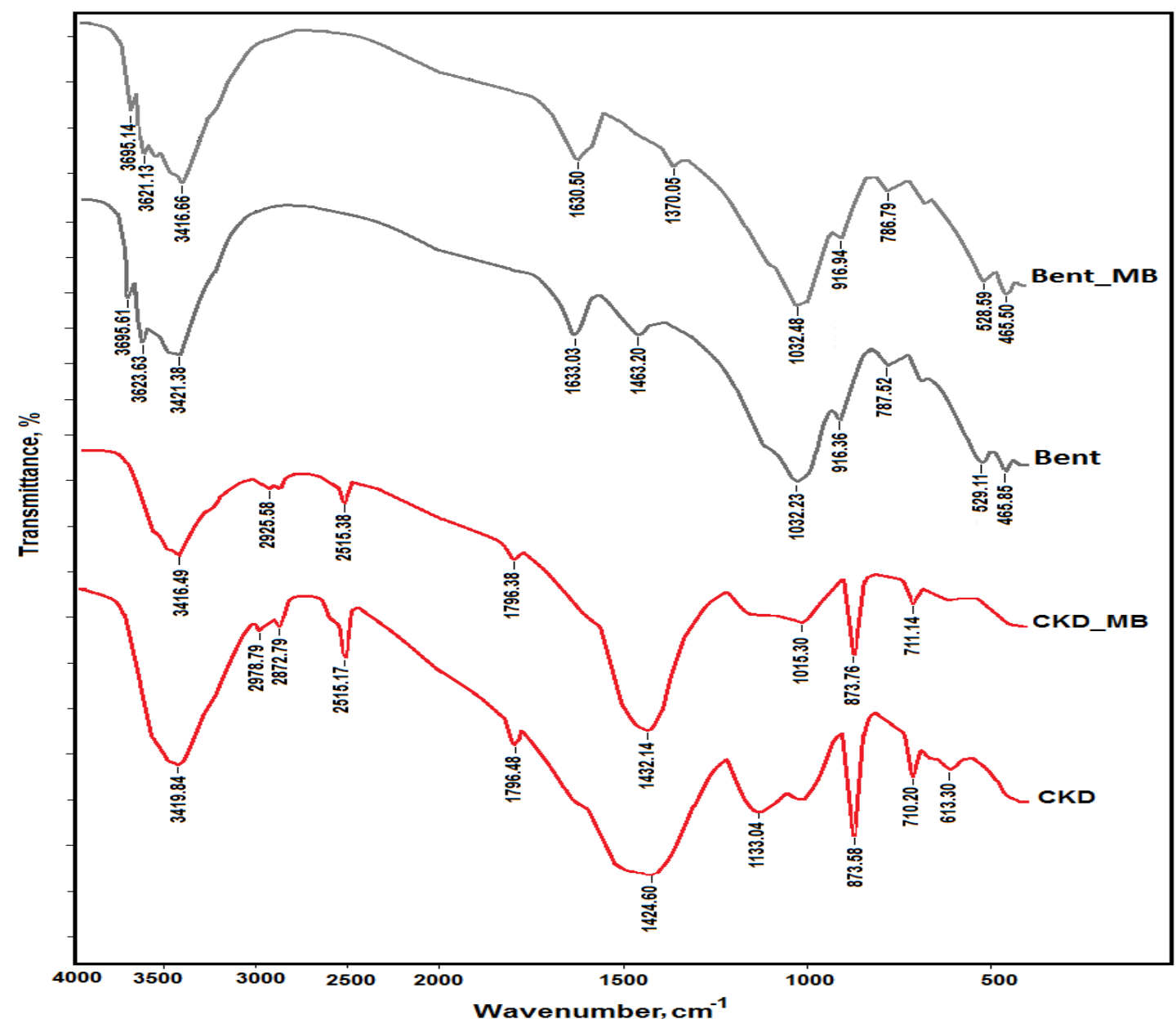

Fig. 4. FTIR spectra of bentonite (Bent) and cement kiln dust (CKD) before and after the methylene blue (MB) dye removal. 


\section{Scanning electron microscopy analysis}

Bentonite and CKD surface morphology was analyzed by scanning electron microscopy (SEM) before and after the removal reaction of methylene blue (MB) dye removal (Fig.5). SEM image demonstrated that bentonite has a clear plate with lamellar curly surface morphology. While, SEM of CKD revealed irregular shape particles distributed heterogeneously. The difference in morphology between before and after MB removal reaction was clearly observed with CKD than with bentonite. Hence, CKD particles were concealed in bulk and complexes formation and it may denote different mechanisms for MB dye removals.

\section{Removal of methylene blue \\ Influence of contact time and initial dye concentration}

The influence of contact time and the initial concentration of $\mathrm{MB}$ dye on the adsorption processes by Bent and CKD are shown in Fig. (6). The results revealed that the MB dye removal was increased with time with rapid removal of $\mathrm{MB}$ dye in the first $60 \mathrm{~min}$ for bentonite and CKD at all tested initial $\mathrm{MB}$ concentrations then slowed the removal down close to equilibrium. The first rapid removal percentage of MB may be ascribed to a large number of binding sites on the adsorbent surfaces, while the slower removal percentage may be occurred after the saturation of the binding sites before reaching the equilibrium (Hameed and Ahmad, 2009; Omer et al., 2018). For bentonite, there was increasing in $\mathrm{MB}$ removal percentage and reaching equilibrium time after $2 \mathrm{~h}$ for $50-100 \mathrm{mg} / \mathrm{L}$. But for MB dye concentration $200-300 \mathrm{mg} / \mathrm{L}, 3 \mathrm{~h}$ was very sufficient (Fig. 6-a). For CKD, the MB dye removal was gradually increased with time till it reached equilibrium after $3 \mathrm{~h}$ and maximum $\mathrm{MB}$ dye removal percentage for all initial concentrations. In general, the equilibrium time, a steady-state approximation, varied depending on various adsorbents and adsorption conditions (Hameed, 2009). Otherwise, the MB dye removal percentage decreases with increasing the concentration from 50 to $300 \mathrm{mg} / \mathrm{L}$. For bentonite, MB dye removal percentage decreased from 92.55 to $42.14 \%$ (Fig. 6-a) and from 73.57to $26.67 \%$ for CKD with increasing the initial $\mathrm{MB}$ concentration from 50 to $300 \mathrm{mg} / \mathrm{L}$ (Fig. 6b).
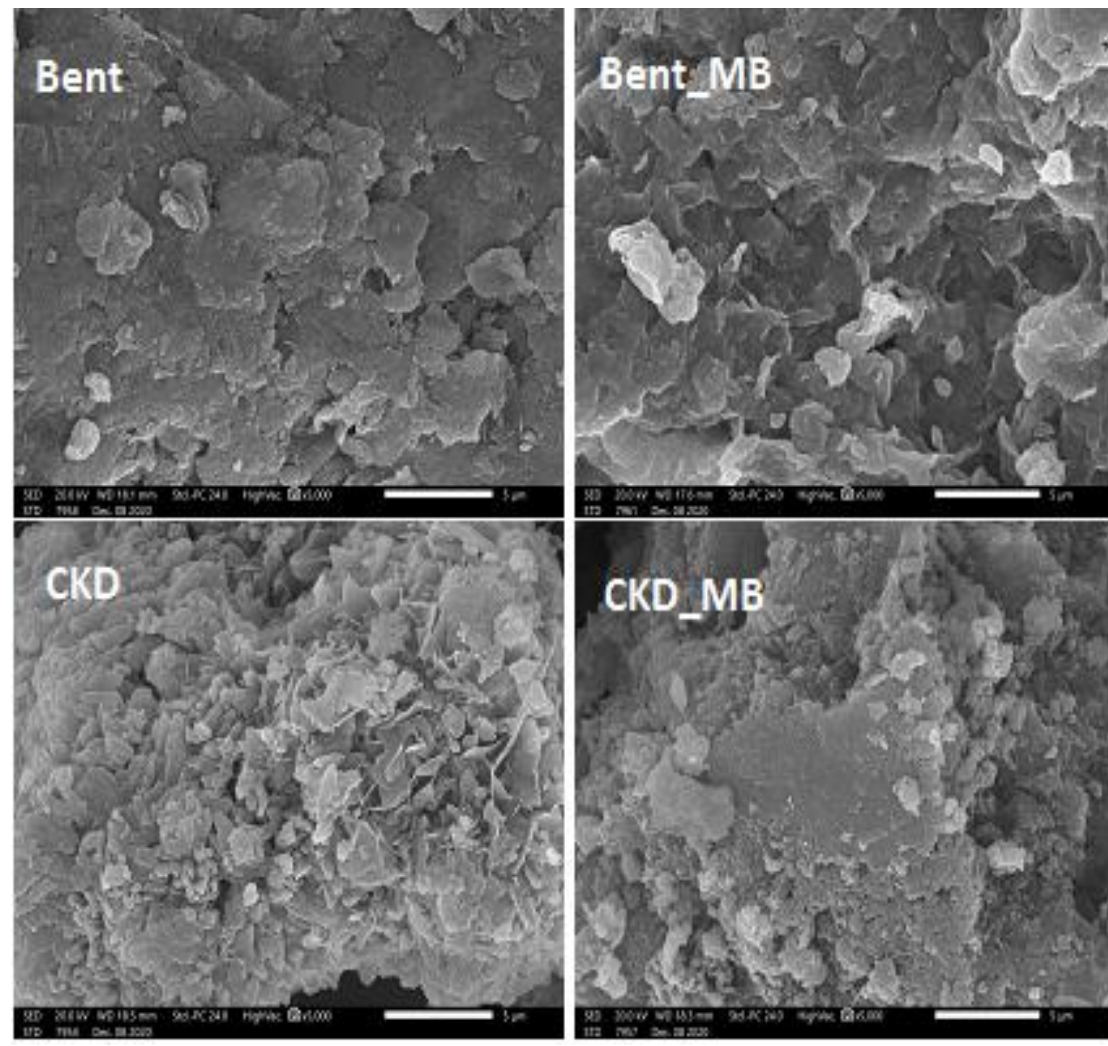

Fig. 5. SEM images analysis of bentonite (Bent) and cement kiln dust (CKD) before and after methylene blue (MB) dye removal reactions from aqueous solutions. 

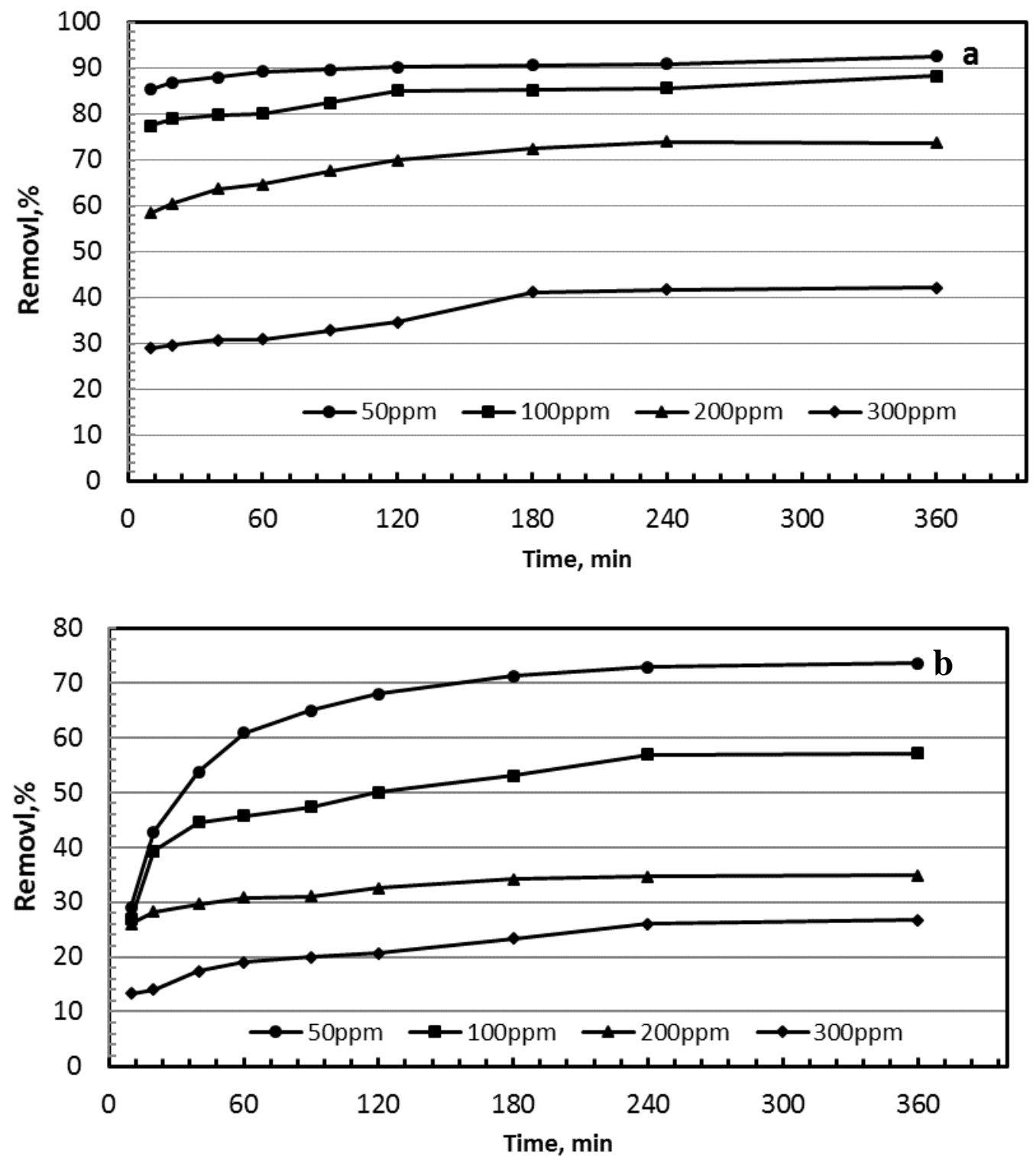

Fig. 6. Kinetic of methylene blue (MB) dye removal by bentonite (a) and cement kiln dust (b) at different initial dye concentrations $(50-300 \mathrm{mg} / \mathrm{L})$ at room temperature $\left(25^{\circ} \mathrm{C}\right)$.

\section{Influence of adsorbent dose}

Generally, gradually increasing the adsorbent mass from $0.05 \mathrm{~g}$ to $1.0 \mathrm{~g}$ (at $100 \mathrm{mgMB} / \mathrm{L}$ ) showed an increase in the MB dye removal by bentonite (Fig. 7-a). The increase of removal percent was due to the increase in the adsorption surface sites. There were close results for bentonite $(88.25 \%)$ and CKD $(84.04 \%)$, at $1.0 \mathrm{~g}$ mass adsorbent. This decrease indicates the role of the ratio of absorbent with a concentration of $\mathrm{MB}$ in the system.

\section{Influence of $\mathbf{p H}$}

One of the affected parameters on the dye removal is the $\mathrm{pH}$ because of its effect on dye molecules ionization process and the adsorbent functional groups (Liu et al, 2014). Results reveal that the removal percentages of MB dye by bentonite and CKD increase with increasing solution $\mathrm{pH}$ from 4 to 12 (Fig. 6-b). At the initial low $\mathrm{pH}$ system, the numbers of surface negative charge sites are decreased, and the surface positive charge sites are 
increased. As a result that the MB dye cation removal decreases because of electrostatic repulsion and the competing of excess $\mathrm{H}^{+}$ions with $\mathrm{MB}$ dye (Tahir and Rauf, 2006; Djelloul and Hamdaoui, 2014). For bentonite, the removal percentage increased from 45.00 to $81.29 \%$ with increasing $\mathrm{pH}$ from 4 to 6 and there were no significant differences in the removal percentage as the $\mathrm{pH}$ value was beyond 6.0. This could be explained as due to clay mineral buffering capacity (Grim, 1968; Bloom, 2000). So, bentonite could be used as an efficient removal sorbent for MB in a considerable $\mathrm{pH}$ range $(6-12)$. For clay minerals, the electric layer polarity change on both the silica and alumina contents from positive to negative charge, especially in the higher $\mathrm{pH}$ and that could increase the dye removal by appealing the dye cations (Tahir and Rauf, 2006; Anirudhan and Ramachandran, 2015; Abd-Elhamid et al., 2019).
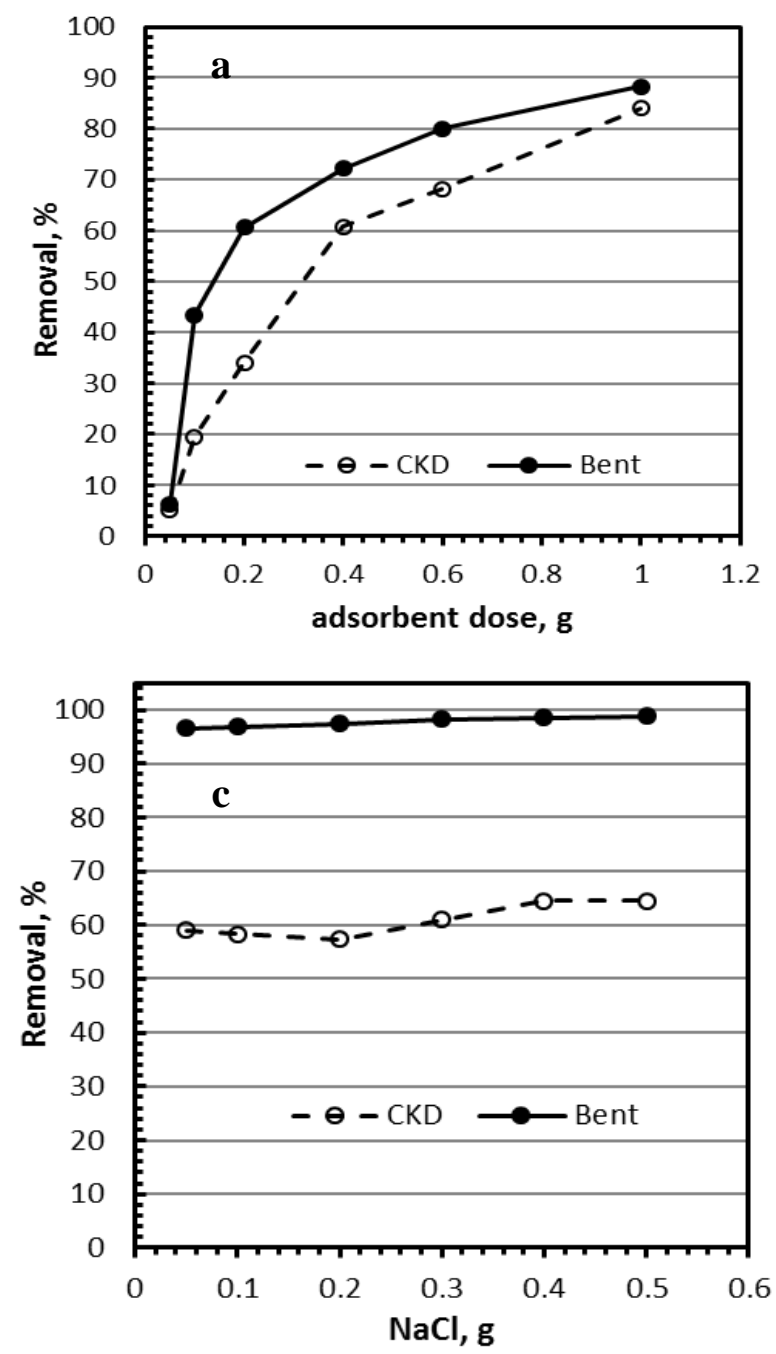

Otherwise, the removals of MB dye by CKD slightly increasing with increasing from $\mathrm{pH} 4$ to 8 . However, a sharp rising in their removal percentage of MB dye by CKD $(84.7 \%)$ at $\mathrm{pH} 12$ revealed that the removal efficiency is considerable at the high alkane range.

\section{Influence of salinity}

Generally, $\mathrm{NaCl}$ is presented in the dyeing industries wastewaters, especially textile industries, for enhancing the fixation of dyes (Liu et al., 2014). So, the effect of salinity on the MB dye removal by bentonite and CKD was investigated in the range of $0.05-0.5 \mathrm{~g}$ of $\mathrm{NaCl}$ (Fig. 7-c). Figure (7-c) showed that the MB dye removal percentage was increased as $\mathrm{NaCl}$ concentration in solution increased, to reach $98.82 \%$ for bentonite and $64.46 \%$ for $\mathrm{CKD}$ at $0.5 \mathrm{~g} \mathrm{NaCl}$.
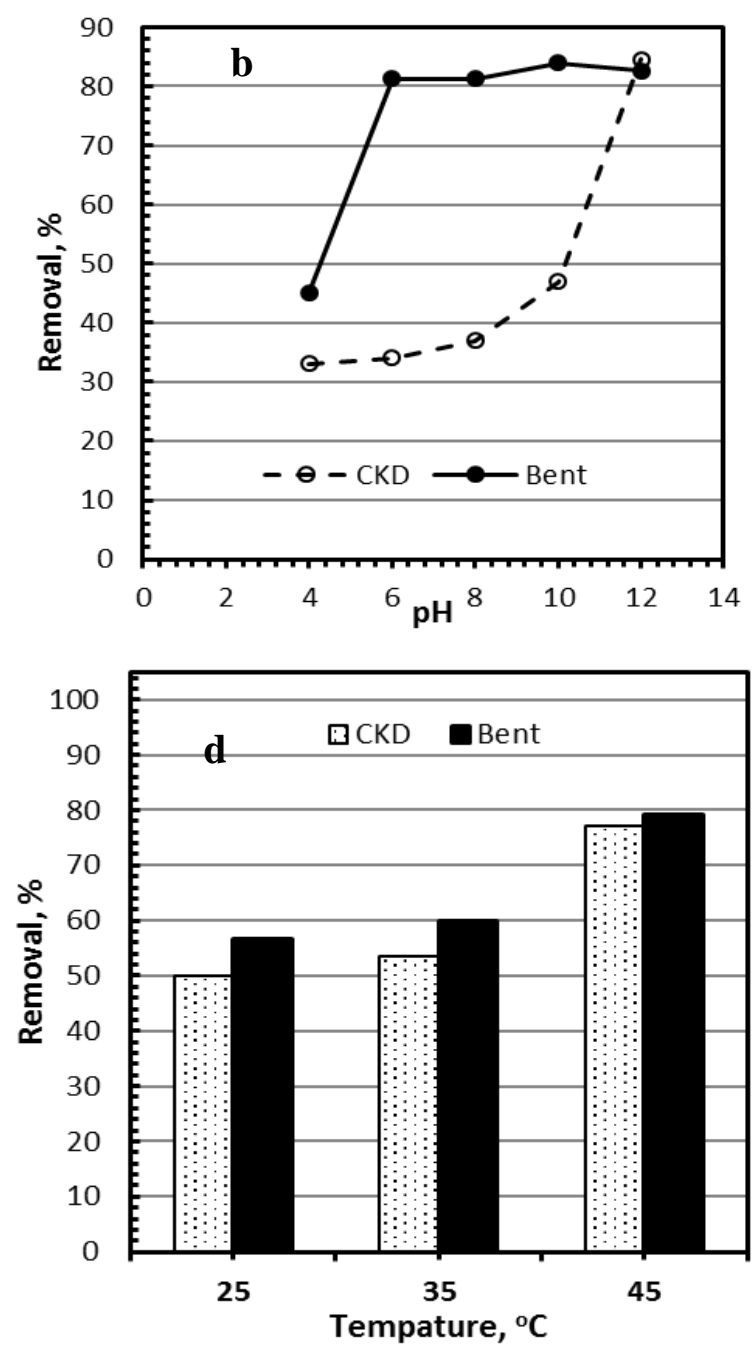

Fig. 7. Effect of adsorbent dose (a), $\mathrm{pH}(\mathrm{b}), \mathrm{NaCl}(\mathrm{c})$ and temperature (d) on the removal percentage of methylene blue (MB) dye by bentonite (Bent) and cement kiln dust (CKD). 
That can be interpreted by the electrostatic force is repulsive with increasing $\mathrm{Na}^{+}$ion concentration (Alberghina et al., 2000; Oladipo et al., 2014). Also, increasing salt concentration, with the $\mathrm{Cl}^{-}$existence, can affect the dissociation of $\mathrm{MB}$ dye molecules by supporting the protonation, and thus the detachment dye ions are encouraged to contact the surface of the adsorbent, toward increasing the capacity of adsorption (Vermohlen et al., 2000; Tekin et al., 2005; Al-Degs et al., 2008; Liu et al., 2014). Clearly, the results indicated that the increase of $\mathrm{NaCl}$ concentration showed a higher progressive effect on the performance of the removal of MB dye by bentonite $(98.82 \%)$ than CKD $(64.46 \%)$ at $0.5 \mathrm{~g} \mathrm{NaCl}$.

\section{Influence of temperature}

The effect of different temperatures $(25,35$, and $45^{\circ} \mathrm{C}$ ) on $\mathrm{MB}$ dye removal onto bentonite and CKD is illustrated in Fig. (7-d). The obtained results indicated the increasing percentage of MB dye removal with increasing the solution temperature for both adsorbents. Xue et al. (2007) and Toor et al. (2015) reported that increasing the temperature could result in deeper penetration of protons into clay layers and the removal of hydrated water provides further adsorption sites and increasing the specific surface area. On other hand, at low temperatures, the water molecules adsorption is higher than that of dye molecules due to their competition in the clay inter-lamellar spaces (Omer et al., 2018).

\section{Kinetic studies}

Different kinetics models were conducted to understand and describe the removal of MB dye by bentonite and CKD. These models are fractional power (Ho and McKay, 2002), Elovich (Inyang et al., 2016), pseudo-first-order (Lagergren, 1898), pseudo-secondorder (Ho, 2006), and intra-particle diffusion (Medria et al., 2020) models. The linear form of the used models:

Fractional power: $\ln \mathrm{q}_{\mathrm{t}}=\ln \mathrm{a}+\mathrm{b} \ln \mathrm{t}$

$$
\text { Elovich: } \quad q_{t}=\frac{1}{\beta} \ln (\alpha \beta)+\frac{1}{\beta} \ln t(4)
$$

Pseudo-first-order:

$\log \left(q_{e}-q_{\mathrm{t}}\right)=\log q_{e}-k_{1} t / 2.303$

Pseudo-second order:

$$
\frac{t}{q_{i}}=1 / k_{2} q_{e}^{2}+{ }^{t} / q_{e}
$$

Intra-particle diffusion: $\quad \mathrm{q}_{\mathrm{t}}=\mathrm{k}_{\mathrm{i}} \mathrm{t}^{1 / 2}+\mathrm{C}$

Where;

$\mathrm{q}_{\mathrm{e}}$ and $\mathrm{q}_{\mathrm{t}}$ equal the MB dye adsorbed ( $\mathrm{mg} \mathrm{g}^{-1}$ ) by bentonite or by CKD at equilibrium and at a time $t$, respectively; $\alpha$ equals primary adsorption coefficient $\left(\mathrm{mg} / \mathrm{g} \mathrm{min}^{-1}\right) ; \beta$ equals desorption coefficient $\left(\mathrm{g} \mathrm{mg}^{-1}\right)$; $\mathrm{k}_{1}$ and $\mathrm{k}_{2}$ equal the rate constants of pseudo-first $\left(\mathrm{min}^{-1}\right)$ and second-order models $\left(\mathrm{g} \cdot \mathrm{mg}^{-1} \mathrm{~min}^{-1}\right)$, respectively; $\mathrm{k}_{\mathrm{i}}\left(\mathrm{gmg}^{-1} \mathrm{~min}^{-1 / 2}\right)$ equals intra-particle diffusion rate constant; $\mathrm{C}$ equals constant $\left(\mathrm{mg} \mathrm{g}^{-1}\right)$ that provides evidence of the boundary layer thickness.

The removal kinetic parameters of different concentrations $(50-300 \mathrm{mgMB} / \mathrm{L})$ onto bentonite and CKD are shown in Table (3). The obtained data for both adsorbents pointed out a good agreement with the second-order equation for all examined initial dye concentrations. For most of the initially tested concentrations of MB dye, the regression coefficients $\left(\mathrm{R}^{2}\right)$ for the two adsorbents regarding pseudo-second order model were more than 0.99 (Table 3). The excellent agreement of the obtained data to pseudosecond- order equation and independent of the rate constants values from initial $\mathrm{MB}$ dye concentration indicated the chemical nature of the adsorption process (Fig. 8) (Wu et al., 2009; Anirudhan and Ramachandran, 2015; Konggidinata et al., 2017; Magdy and Altaher, 2018).

Under aqueous conditions, the surface negative charged functional groups drive the adsorption of dye molecules into adsorbents. However, this can be assigned mainly to be through the ion exchange process (Hassan and Carr, 2018). For bentonite, montmorillonite as the main content has a net surface negative charge due to isomorphic substitutions on its structure and compensates with interlayer cations that can be replaced by MB cations (Zhu et al., 2009; Şahin et al., 2015). Swelling may be having a significant role in increasing its inner specific surface area and pore size ( $\mathrm{Li}$ et al., 2019). Also, metal oxides and hydroxides in the adsorbent surfaces could form complexes with dye in an aqueous solution (Netpradit, et al., 2003). However, the adsorption of MB dye by bentonite and CKD could take place through different stages. In the beginning, the dye molecules move to form a thin layer surrounding the hydrated adsorbent, and then the dye particles diffuse through the thin hydration shell around the adsorbent. After that the dye particles penetrate into the adsorbent surface through the pores, finally, it is adsorbed on the adsorbent surfaces (Tahir and Rauf, 2006; Fierro et al., 2008; Magdy and Altaher, 2018).

\section{Adsorption isotherm studies}

The isotherm analysis gives an idea of how the adsorbent will relate to the adsorbent and its adsorption capacity (Salleh et al., 2011). The results of the isotherms experiments were analyzed using Freundlich (Freundlich, 1906), Langmuir (Langmuir, 1918), 
Table 3. Kinetic parameters for the removal of methylene blue (MB) dye onto bentonite and cement kiln dust (CKD).

\begin{tabular}{|c|c|c|c|c|c|c|c|c|}
\hline \multirow{2}{*}{ model } & \multicolumn{3}{|c|}{ Bentonite } & \multirow[b]{2}{*}{$300 \mathrm{mg} / \mathrm{L}$} & \multicolumn{4}{|c|}{ CKD } \\
\hline & $50 \mathrm{mg} / \mathrm{L}$ & $100 \mathrm{mg} / \mathrm{L}$ & $200 \mathrm{mg} / \mathrm{L}$ & & $50 \mathrm{mg} / \mathrm{L}$ & $100 \mathrm{mg} / \mathrm{L}$ & $200 \mathrm{mg} / \mathrm{L}$ & $300 \mathrm{mg} / \mathrm{L}$ \\
\hline \multicolumn{9}{|c|}{ Fractional power } \\
\hline $\mathrm{a}$ & 40531.96 & 70260.17 & 97713.20 & 61033.30 & 3575.39 & 10500.53 & 43432.99 & 23892.09 \\
\hline $\mathrm{b}$ & 0.200 & 0.036 & 0.072 & 0.119 & 0.453 & 0.321 & 0.084 & 0.207 \\
\hline $\mathrm{R}^{2}$ & 0.984 & 0.933 & 0.976 & 0.847 & 0.664 & 0.672 & 0.981 & 0.981 \\
\hline \multicolumn{9}{|l|}{ Elovich } \\
\hline$\alpha$ & $1.063 \times 10^{19}$ & $2.924 \times 10^{13}$ & $1.48 \times 10^{8}$ & $6.53 \times 10^{5}$ & 3743.57 & 10665.20 & 5406.36 & 5406.36 \\
\hline$\beta$ & 0.0010778 & 0.000331 & 0.0001039 & 0.00008 & 0.00012 & 0.000094 & 0.000195 & 0.000084 \\
\hline $\mathrm{R}^{2}$ & 0.8733 & 0.928 & 0.972 & 0.824 & 0.853 & 0.853 & 0.981 & 0.964 \\
\hline \multicolumn{9}{|c|}{ Pseudo-first-order } \\
\hline $\mathrm{q}_{\mathrm{e}}$ & 3127.99 & 10646.44 & 37317.78 & 68927.64 & 25032.41 & 27207.36 & 27346.73 & 39849.20 \\
\hline $\mathrm{k}_{1}$ & -0.00331 & -0.0067 & -0.0134 & -0.01543 & -0.01982 & -0.00501 & -0.01511 & -0.00873 \\
\hline $\mathrm{R}^{2}$ & 0.905 & 0.899 & 0.942 & 0.973 & 0.965 & 0.839 & 0.942 & 0.97315 \\
\hline \multicolumn{9}{|c|}{ Pseudo-second-order } \\
\hline $\mathrm{q}_{\mathrm{e}}$ & 45454.55 & 90909.09 & 142857.14 & 125000 & 41666.66 & 62500.00 & 71428.57 & 83333.33 \\
\hline $\mathrm{K}_{2}$ & 0.000002 & 0.000002 & 0.0000011 & 0.0000005 & 0.0000007 & 0.0000007 & 0.0000018 & 0.0000005 \\
\hline $\mathrm{R}^{2}$ & 0.999 & 0.999 & 0.999 & 0.994 & 0.980 & 0.995 & 0.999 & 0.992 \\
\hline \multicolumn{9}{|c|}{ Intra-particle diffusion } \\
\hline $\mathrm{k}_{\mathrm{i}}$ & 200.90 & 686.70 & 2110.40 & 2981.69 & 1590.00 & 2082.40 & 1112.70 & 2674.20 \\
\hline $\mathrm{C}$ & 42652 & 75666 & 113316 & 74453 & 12849 & 24384 & 51536 & 33360 \\
\hline $\mathrm{R}^{2}$ & 0.913 & 0.655 & 0.925 & 0.913 & 0.652 & 0.6555 & 0.915 & 0.966 \\
\hline
\end{tabular}

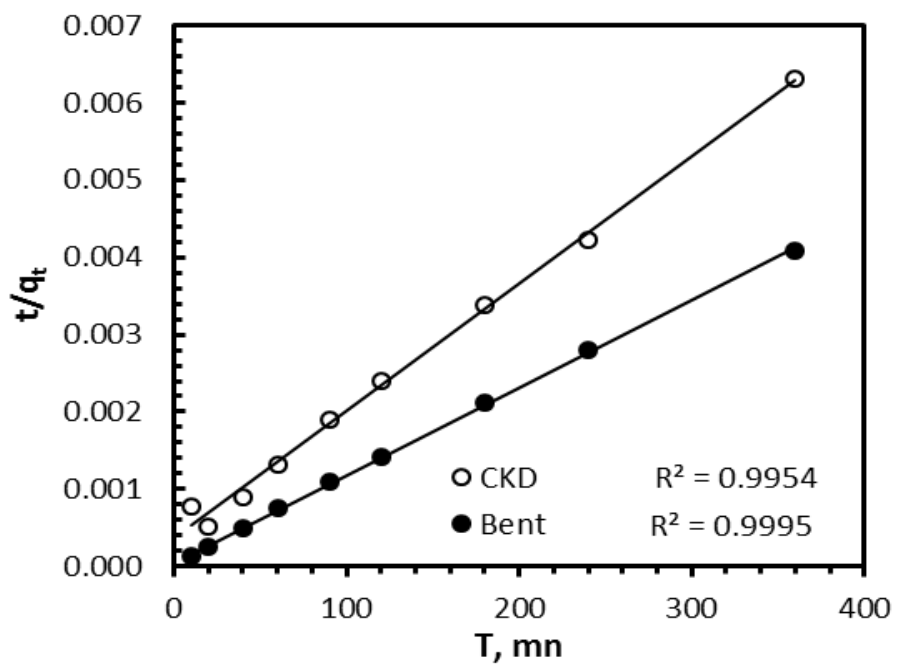

Fig. 8. Pseudo-second-order plots for methylene blue (MB) dye (at 100mgMB/L) removal kinetics by bentonite (Bent) and cement kiln dust (CKD)

and Temkin (El-Refaey and Mohammad, 2019) isotherm models as follows:

Freundlich: $\quad \mathrm{q}_{\mathrm{e}}=\mathrm{K}_{\mathrm{F}} \mathrm{C}_{\mathrm{e}}{ }^{1 / n}$

Langmuir:

$\mathrm{q}_{\mathrm{e}}=\mathrm{q}_{\max }\left(\mathrm{K}_{\mathrm{L}} \mathrm{C}_{\mathrm{e}} / 1+\mathrm{K}_{\mathrm{L}} \mathrm{C}_{\mathrm{e}}\right)$

Temkin:

$\theta=\mathrm{RT} / \Delta \mathrm{Q} \ln \mathrm{K}_{0} \mathrm{C}_{\mathrm{e}}$

Where:

$\mathrm{q}_{\mathrm{e}}$ : $\mathrm{MB}$ dye adsorbed $\left(\mathrm{mg} \mathrm{\textrm {g } ^ { - 1 }}\right), \mathrm{C}_{\mathrm{e}}$ : equilibrium concentration of $\mathrm{MB}$ dye $\left(\mathrm{mg} \mathrm{L}^{-1}\right), \mathrm{K}_{\mathrm{F}}$ : constant associated with the adsorption capacity $\left(\mathrm{mg}^{1-(1 / \mathrm{n})}\right.$ $\left.\mathrm{L}^{1 / \mathrm{n}} \mathrm{g}^{-1}\right)$, n: a constant, $\mathrm{q}_{\max }$ : maximum adsorption capacity $\left(\mathrm{mg} \mathrm{g}^{-1}\right), \mathrm{K}_{\mathrm{L}}$ : constant associated with the adsorption free energy $\left(\mathrm{L} \mathrm{mg}^{-1}\right), \theta$ : fractional coverage, $\mathrm{R}$ : universal gas coefficient $\left(\mathrm{kJ} \mathrm{mol}^{-1} \mathrm{~K}^{-1}\right), \mathrm{T}$ : 
temperature $\left({ }^{\circ} \mathrm{K}\right), \quad \Delta \mathrm{Q}: \quad(-\Delta \mathrm{H})$ adsorption energy difference $\left(\mathrm{kJ} \mathrm{mol}^{-1}\right)$, and $\mathrm{K}_{0}$ : Temkin coefficient ( $\mathrm{L}$ $\mathrm{mg}^{-1}$ ).

The isotherm parameters of methylene blue (MB) dye removed by bentonite (Bent) and CKD are shown in Table (4). The results were fitted within the following isotherms order: Langmuir $>$ Freundlich $>$ Temkin according to regression coefficients values $\left(\mathrm{R}^{2}\right)$ for both adsorbents (Table.4). The equilibrium was excellently fitted to Langmuir isotherm and $\mathrm{R}^{2}$ for bentonite and CKD were 0.994 and 0.996, respectively (Fig.9). The Langmuir isotherm was established to represent the chemisorption. According to Langmuir model theory, the sorption is confined in a mono-layer, nointeraction among the MB dye particles, and no additional adsorption occurred on a site after a dye molecule has occupied this site (Wang and Ariyanto, 2007; Liu et al., 2014). The maximum sorption capacity of bentonite for MB dye (3257.33 $\mathrm{mg} \mathrm{g}^{-1}$ ) was significantly higher than that of CKD (2150.54 $\mathrm{mg} \mathrm{g}^{-1}$ ) (Table.4). The presented result that the adsorbent used in this study indicated higher adsorption capacity as compared to those prepared from agricultural waste (Kadhom et al., 2020), ion-exchange resin adsorbents (Hassan and Carr, 2018), and activated carbon derived from any carbonaceous raw material (Katheresan et al., 2018).

\section{Thermodynamic studies}

Thermodynamic parameters of MB dye removal onto bentonite and CKD surfaces were determined using van't Hoff relation in the range of temperature was 298$318{ }^{\circ} \mathrm{K}$. The following equations used for the estimation of Gibbs free energy $\left(\Delta \mathrm{G}^{\circ}\right)$, enthalpy change $\left(\Delta \mathrm{H}^{\circ}\right)$, and the entropy change $\left(\Delta \mathrm{S}^{\circ}\right)$ parameters (Trana et al., 2016; El-Refaey, 2017, Danish et al., 2018):

$\Delta \mathrm{G}^{\circ}=-\mathrm{RT} \ln \mathrm{K}_{\mathrm{L}}$

$\Delta \mathrm{G}^{\circ}=\Delta \mathrm{H}^{\circ}-\mathrm{T} \Delta \mathrm{S}^{\circ}$

$\ln \mathrm{K}_{\mathrm{L}}=-\frac{\Delta \mathrm{G}^{\mathrm{D}}}{R T}=-\frac{\Delta \mathrm{H}^{\mathrm{a}}}{R T}+\frac{\Delta S^{\mathrm{D}}}{R}$

Where:

$\mathrm{R}$ : gas coefficient $(8.314 \mathrm{~J} / \mathrm{mol} \mathrm{K}), \mathrm{K}_{\mathrm{L}}$ : equilibrium constant obtained by divided $\mathrm{MB}$ adsorbed dye $\left(\mathrm{q}_{\mathrm{e}}, \mathrm{mg}\right.$ $\left.\mathrm{g}^{-1}\right)$ by the equilibrium concentration of $\mathrm{MB}$ dye $\left(\mathrm{C}_{\mathrm{e}}, \mathrm{mg}\right.$ $\left.\mathrm{L}^{-1}\right)$ and $\mathrm{T}$ : absolute temperature $\left({ }^{\circ} \mathrm{K}\right)$.

The determined thermodynamic values of Gibbs free energy change $\left(\Delta \mathrm{G}^{\circ}\right)$, enthalpy $\left(\Delta \mathrm{H}^{\circ}\right)$, and entropy $\left(\Delta \mathrm{S}^{\circ}\right)$ are shown in Table (5). The negative values of $\Delta \mathrm{G}^{\circ}$ for removal of $\mathrm{MB}$ dye by bentonite and CKD indicate that the adsorption is spontaneous and the feasibility of the process for both sorbents (Table 5). The decrease of $\Delta \mathrm{G}^{\circ}$ values for the $\mathrm{MB}$ dye removal by bentonite and CKD with increasing temperature gives an increase in the process feasibility and becomes more favorable at higher temperatures. The $\Delta \mathrm{H}^{\circ}$ positive value for bentonite pointed out that the nature of the adsorption process is endothermic. Spontaneous and endothermic adsorptions have also been described by Hong et al. (2009), Chinoune et al. 2016, and Omer et al. (2018) for bentonite, and Kadhim and Hassan (2016) for CKD. The positive value of $\Delta \mathrm{S}^{\circ}$ reflects the affinity of bentonite and $\mathrm{CKD}$ for removing $\mathrm{MB}$ dye and suggests growing the randomness at the solid/solution interface through the removal reactions.

Table 4. Adsorption isotherm parameters of methylene blue (MB) dye by bentonite (Bent) and cement kiln dust (CKD).

\begin{tabular}{|c|c|c|c|c|c|c|c|c|c|}
\hline & \multicolumn{3}{|c|}{ Freundlich } & \multicolumn{3}{|c|}{ Langmuir } & \multicolumn{3}{|c|}{ Temkin } \\
\hline & $\begin{array}{c}\mathbf{K}_{\mathbf{F}} \\
\mathrm{mg}^{1-(1 / \mathrm{n})} \mathbf{L}^{1 / \mathbf{n}^{-1}}\end{array}$ & $1 / \mathbf{n}$ & $\mathbf{R}^{2}$ & $\begin{array}{c}\mathbf{q} \mathbf{m} \\
\mathbf{m g ~ g}^{-1}\end{array}$ & $\begin{array}{c}\mathrm{K}_{\mathrm{L}} \\
\mathbf{L m g}^{-1}\end{array}$ & $\mathbf{R}^{2}$ & $\begin{array}{c}A \\
L_{\mathbf{g}^{-1}}\end{array}$ & B & $\mathbf{R}^{2}$ \\
\hline Bent & 972.71 & 0.271 & 0.785 & 3257.33 & 0.031 & 0.994 & 3.218 & 580.9 & 0.771 \\
\hline CKD & 481.32 & 0.268 & 0.973 & 2150.54 & 0.046 & 0.996 & 0.96 & 371.09 & 0.991 \\
\hline
\end{tabular}

Table 5. Thermodynamic parameters of methylene blue (MB) dye removal by bentonite (Bent) and cement kiln dust (CKD) from aqueous solutions at temperature range from 298 to $323 \pm 2{ }^{\circ} \mathrm{K}$.

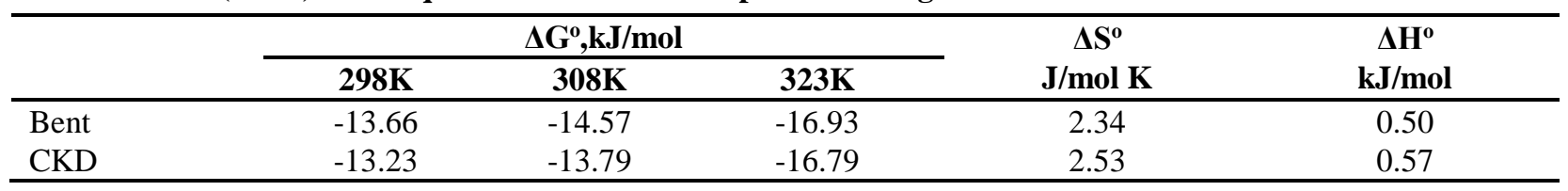




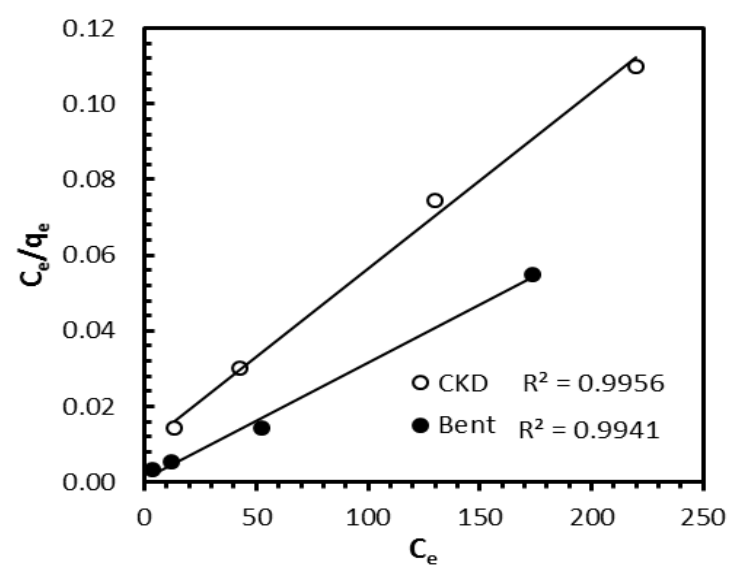

Fig. 9. Methylene blue (MB) dye adsorption isotherm regression using the Langmuir equation for bentonite (Bent) and cement kiln dust (CKD)

\section{CONCLUSION}

The chemical composition and surface characteristics of bentonite and cement kiln dust were investigated by XRF, XRD, BET specific surface area, FTIR, and SEM analysis. The results of batch experiments indicated that the methylene blue (MB) dye removal has been increased with time and decreased as its initial concentration increased. On the other hand, increasing the dose of adsorbent increased the dye removal percentage by both adsorbents. The removal of $\mathrm{MB}$ dyes onto bentonite was slightly $\mathrm{pH}$ dependent at $\mathrm{pH}>6$ with a maximum removal percent of $81.29 \%$ at $\mathrm{pH}$ 12. Otherwise, the removal percent of MB dye by CKD increased with $\mathrm{pH}$ increase to reach its maximum $(84.7 \%)$ at $\mathrm{pH} 12$. The bentonite adsorption capacity was also increased by the presence of $\mathrm{NaCl}$ compared to CKD. Langmuir isotherm was a preferable fit for the experimental results for both adsorbents. The maximum adsorption capacity for bentonite and CKD were $3257.33 \mathrm{mg} \mathrm{g}^{-1}$ and $2150.54 \mathrm{mg} \mathrm{g}^{-1}$, respectively. Kinetic data for MB dye removal by bentonite and CKD obeyed the pseudo-second-order at all tested concentrations. The high removal of MB dye indicated a high potential for the two adsorbents. For economic issues, CKD proved to be effective and to be applied for removing $\mathrm{MB}$ dye from wastewater at the same time; it is considered a value-added product valuable for hazardous waste disposal in waterways.

\section{ACKNOWLEDGE}

The author thanks Dr. Mohamed A. Osman for his cooperation in XRD identification.

\section{REFERENCES}

Abd-Elhamid, A. I., F. E. Gomaa, A. A. Magda. 2019. Methylene Blue and Crystal Violet Dyes Removal (As A Binary System) from Aqueous Solution Using Local Soil Clay: Kinetics Study and Equilibrium Isotherms. Egypt. J. Chem. 62(3): $941-954$.

https://doi.org/10.21608/EJCHEM.2018.4113.1360

Alberghina G., R. Bianchini, M. Fichera, S. Fisichella. 2000. Dimerization of cibacron blue F3GA and other dyes: influence of salts and temperature. Dyes Pigm.46:129-37. https://doi.org/10.1016/S0143-7208(00)00045-0

Al-Degs Y.S., M.I. El-Barghouthi, A.H. El-Sheikh, G.M. Walker. 2008. Effect of solution $\mathrm{pH}$, ionic strength, and temperature on adsorption behavior of reactive dyes on activated carbon. Dyes Pigm.77: 16- 23.

https://doi.org/10.1016/j.dyepig.2007.03.001

Al-Ghouti, M. A., M. A. M. Khraisheh, S. J. Allen, M. N. Ahmad. 2003. The removal of dyes from textile wastewater: a study of the physical characteristics and adsorption mechanisms of diatomaceous earth. J. Environ. Manage. 69: 229-238.

https://doi.org/10.1016/j.jenvman.2003.09.005

Anirudhan, T.S., M. Ramachandran. 2015. Adsorptive removal of basic dyes from aqueous solutions by surfactant modified bentonite clay (organoclay): Kinetic and competitive adsorption isotherm. Process Saf. Environ. Prot. 95:215-225.

https://doi.org/10.1016/j.psep.2015.03.003

Bello, O.S., K.A. Adegoke, , A.A. Olaniyan, H. Abdulazeez. 2015. Dye adsorption using biomass wastes and natural adsorbents: overview and future prospects. Desalin. Water Treat. 53: 1292-1315.

https://doi.org/10.1080/19443994.2013.862028

Benhouria, A., M.A. Islam, H. Zaghouane-Boudiaf, M. Boutahala, B.H. Hameed. 2015. Calcium alginatebentonite-activated carbon composite beads as highly effective adsorbent for methylene blue. Chem. Eng. J. 270: 621-630. https://doi.org/10.1016/j.cej.2015.02.030

Bloom, P.R. 2000. Soil $\mathrm{pH}$ and $\mathrm{pH}$ buffering. In Sumner: M.E., (ed.). Handbook of Soil Science CRC Press. USA.pp. 333-352

Bulgariu, L., L.B. Escudero, O.S. Bello, M. Iqbal, J. Nisar, K.A. Adegoke, F. Alakhras, M. Kornaros, I.,Anastopoulos. 2019. The utilization of leaf-based adsorbents for dyes removal: A review. J. Mol. Liq. 276: 728-747. https://doi.org/10.1016/j.molliq.2018.12.001

Chinoune, K., K. Bentaleb, Z. Bouberka, A. Nadim, U. Maschke. 2016. Adsorption of reactive dyes from aqueous solution by dirty bentonite. Appl. Clay Sci. 123: 64-75. https://doi.org/10.1016/j.clay.2016.01.006

Chudgar, R.J., J. Oakes. 2014. Dyes, azo. In: Kirk-Othmer Encycl. Chem. Technol. Hoboken NJ, USA: John Wiley \& Sons, Inc. 
Danish, M., T. Ahmad, S. Majeed, M. Ahmad, L. Ziyang, Z. Pin, S. M. Shakeel Iqubal. 2018. Use of banana trunk waste as activated carbon in scavenging methylene blue dye: Kinetic, thermodynamic, and isotherm studies. Bioresour. Technol. Reports 3: 127-137. https://doi.org/10.1016/j.biteb.2018.07.007

Djelloul, C., O. Hamdaoui. 2014. Removal of cationic dye from aqueous solution using melon peel as nonconventional low-cost sorbent. Desalin. Water Treat. 52: 7701-7710.

https://doi.org/10.1080/19443994.2013.833555

El Mouzdahir, Y. ,A. Elmchaouri, R. Mahboub, A. Gil, S. A. Korili. 2010. Equilibrium modeling for the adsorption of methylene blue from aqueous solutions on activated clay minerals, Desalination. 250: $335-\quad 338$. https://doi.org/10.1016/j.desal.2009.09.052

El-Latif, M.M..A., A. M. Ibrahim,M. F. El-Kady. 2010. Adsorption equilibrium, kinetics and thermodynamics of methylene blue from aqueous solutions using biopolymer oak sawdust composite. J. Am. Sci. 6: 267-283.

El-Refaey, A.A. 2016. Comparative performance of cement kiln dust and activated carbon in removal of cadmium from aqueous solutions. Water Sci. Technol. 73. https://doi.org/10.2166/wst.2015.651

El-Refaey, A.A. 2017. Investigation of copper removal from aqueous solution by cement kiln dust as industrial byproduct, Alexandria Sci. Exch. J., 38: 149-158. https://doi.org/ 10.21608/ASEJAIQJSAE.2017.2455

El-Refaey, A.A., S.G.Mohamed. 2019. Removal of lead from aqueous solutions using cantaloupe peels as a biosorbent vs. cement kiln dust as an industrial by-product. Desalin. Water Treat. 166: 62-71.

https://doi.org/10.5004/dwt.2019.24626

Fayoud, N., S. Tahiri, S. Alami Younssi, A. Albizane, D. Gallart-Mateu, M. L. Cervera, M. de la Guardia. 2016. Kinetic, isotherm and thermodynamic studies of the adsorption of methylene blue dye onto agro-based cellulosic materials. Desalin. Water Treat. 57:1661116625. https://doi.org/10.1080/19443994.2015.1079249

Fierro,V., V. Torné-Fernández, D. Montané, A. Celzard. 2008. Adsorption of phenol onto activated carbons having different textural and surface properties, Microporous Mesoporous Mat. 111: 276-284. http://dx.doi.org/10.1016/j.micromeso.2007.08.002.

Freundlich,H. M. F.1906. Over the adsorption in solution, J. Phys. Chem. 57: 385-471

Grim, R. E.1968. Clay mineralogy, 2nd ed. McGraw-Hill, New York.

Hameed, B.H. 2009. Grass waste: A novel sorbent for the removal of basic dye from aqueous solution. J. Hazard. Mater. 166: 233-238.

https://doi.org/10.1016/j.jhazmat.2008.11.019

Hameed, B.H., A. A. Ahmad. 2009. Batch adsorption of methylene blue from aqueous solution by garlic peel, an agricultural waste biomass. J. Hazard. Mater. 164: 870875. https://doi.org/10.1016/j.jhazmat.2008.08.084
Hassan, M.M., C. M. Carr. 2018. A critical review on recent advancements of the removal of reactive dyes from dyehouse effluent by ion-exchange adsorbents. Chemosphere. 209: 201-219.

https://doi.org/10.1016/j.chemosphere.2018.06.043

Ho, Y. S. 2006. Second-order kinetic model for the sorption of cadmium onto tree fern: a comparison of linear and nonlinear methods. Water Res. $40 \quad$ (1): 119125.https://doi.org/10.1016/j.watres.2005.10.040

Ho, Y. S., G. McKay. 2002. Application of kinetic models to the sorption of copper (II) on to peat. Adsorp. Sci Technol. 20 (8): 797-815.

https://doi.org/10.1260/026361702321104282

Hong, S., C. Wen, J. He, F. Gan, Y. S. Ho. 2009. Adsorption thermodynamics of Methylene Blue onto bentonite. J. Hazard. Mater. 167:630-633.

https://doi.org/10.1016/j.jhazmat.2009.01.014

Imran, M., D. E. Crowley, A. Khalid, S. Hussain, M.W. Mumtaz, M. Arshad. 2015. Microbial biotechnology for decolorization of textile wastewaters. Rev. Environ. Sci. Biotechnol. 14: 73-92. https://doi.org/10.1007/s11157014-9344-4

Inyang, H. I., A. Onwawoma, S. Bae. 2016. The Elovich equation asa predictor of lead and cadmium sorption rates on contaminant barrier minerals. Soil Tillage Res. 155: 124 - 132. https://doi.org/10.1016/j.still.2015.07.013

Kadhim, D.A., S. A. Hassan. 2016. The performance of Cement Kiln Dust in Removal of Some Dyes from Aqueous Solutions . Am. J. Pharm Tech Res. 6:298-324.

Kadhom, M., N. Albayati, H. Alalwan, M. Al-Furaiji. 2020. Removal of dyes by agricultural waste. Sustain. Chem. Pharm. 16:100259.

https://doi.org/10.1016/j.scp.2020.100259

Katheresan, V., J. Kansedo, S. Y. Lau. 2018. Efficiency of various recent wastewater dye removal methods: A review. J. Environ. Chem. Eng. 6: 4676-4697.

https://doi.org/10.1016/j.jece.2018.06.060

Khan, S., A. Malik. 2018. Toxicity evaluation of textile effluents and role of native soil bacterium in biodegradation of a textile dye. Environ Sci Pollut Res Int. 25(5): 4446-4458. https://doi.org/10.1007/s11356-0170783-7

Konggidinata, M.I., B. Chao, Q. Lian, R. Subramaniam, M. Zappi, D.D. Gang. 2017. Equilibrium, kinetic and thermodynamic studies for adsorption of BTEX onto Ordered Mesoporous Carbon (OMC). J. Hazard. Mater. 336: 249-259.

https://doi.org/10.1016/j.jhazmat.2017.04.073

Kumararaja , P., K. M. Manjaiaha, S. C. Datta, B. Sarkar. 2017. Remediation of metal contaminated soil by aluminium pillared bentonite: Synthesis, characterisation, equilibrium study and plant growth experiment. Appl. Clay Sci.137: 115-122.

https://doi.org/10.1016/j.clay.2016.12.017 
Lagergren, S., 1898. About the theory of so-called adsorption of soluble substances. Kungliga Svenska Vetenskapsakademiens 24 (4):1-39.

Langmuir, S. 1918. The adsorption of gases on plane surfaces of glass, mica and platinum. J. Am. Chem. Soc. 40 (9): 1361-1403. https://doi.org/10.1021/ja02242a004

Lellis, B., C.Z. Fávaro-Polonio, J.A. Pamphile, J. C. Polonio. 2019. Effects of textile dyes on health and the environment and bioremediation potential of living organisms. Biotechnol. Res. Innov. 3: 275-290. https://doi.org/10.1016/j.biori.2019.09.001

Li,W., B. Mu, Y. Yang. 2019. Feasibility of industrial-scale treatment of dye wastewater via bio-adsorption technology. Bioresour. Technol., 277:157-170. https://doi.org/10.1016/j.biortech.2019.01.002

Liu, Y., Y. Kang, B. Mu, A. Wang. 2014. Attapulgite/bentonite interactions for methylene blue adsorption characteristics from aqueous solution. Chem. Eng. J. 237: 403-410.

https://doi.org/10.1016/j.cej.2013.10.048

Magdy, Y.H., H. Altaher. 2018. Kinetic analysis of the adsorption of dyes from high strength wastewater on cement kiln dust. J. Environ. Chem. Eng. 6: 834-841. https://doi.org/10.1016/j.jece.2018.01.009

Medria, V., E. Papa, M. Mor, A. Vaccari, A. Natali Murri, L. Piotte, C. Melandri, E. Landi. 2020. Mechanical strength and cationic dye adsorption ability of metakaolin-based geopolymer spheres. Appl. Clay Sci. 193: 105678. https://doi.org/10.1016/j.clay.2020.105678

Meziti, C., A. Boukerroui. 2012. Removal of a basic textile dye from aqueous solution by adsorption on regenerated clay. Procedia Eng. 33: 303-312.

https://doi.org/10.1016/j.proeng.2012.01.1208

Miller, G. A., S. Azad. 2000. Influence of soil type on stabilization with cement kiln dust. Constr Build Mater. 14(2): $\quad 89-97 . \quad$ https://doi.org/10.1016/S09500618(00)00007-6

Nader, M. 2015. Surface area: Brunauer-Emmett-Teller (BET). In: Progress in Filtration and Separation (S. Tarleton, ed.). Academic Press, London, UK, pp. 585-608

Netpradit, S., P. Thiravelyan, S. Twoprayoon. 2003..Application of waste metal hydroxide sludge for adsorption of azo reactive dyes. Water Res. 37(4): 763772. https://doi.org/10.1016/S0043-1354(02)00375-5

Oladipo, A.A., M. Gazi, S. Saber-Samandari. 2014. Adsorption of anthraquinone dye onto eco-friendly semiIPN biocomposite hydrogel: Equilibrium isotherms, kinetic studies and optimization. J. Taiwan Inst. Chem. Eng. 45:653-664 https://doi.org/10.1016/j.jtice.2013.07.013

Omer,O. S., M. A. Hussein, B. H. M. Hussein, A. Mgaidi. 2018. Adsorption thermodynamics of cationic dyes (methylene blue and crystal violet) to a natural clay mineral from aqueous solution between 293.15 and 323.15 $\square$ K. Arab. J. Chem., 11(5): 615-623. https://doi.org/10.1016/j.arabjc.2017.10.007
Osman, M.A., F. M. Kishk, A. A. Moussa, H. M. Gaber. 2017. Sorption and Desorption of Atrazine on Natural Bentonite and Organically Modified Bentonite. Alexandria Sci. Exch. J. An Int. Q. J. Sci. Agric. Environ. 38: 271-283. https://doi.org/10.21608/asejaiqjsae.2017.3475

Pai, S., M. S. Kini, R. Selvaraj. 2021. A review on adsorptive removal of dyes from wastewater by hydroxyapatite nanocomposites. Environ. Sci. Pollut. Res. 28:1183511849. https://doi.org/10.1007/s11356-019-07319-9

Paluszkiewicz, C., M. Holtzerb, A. Bobrowski. 2008. FTIR analysis of bentonite in moulding sands. J. Mol. Struct. 880: 109-114.

https://doi.org/10.1016/j.molstruc.2008.01.028

Pavia, D.L., G. M. Lampman, G. S. Kriz, J. R., Vyvyan. 2009. Introduction to Spectroscopy. $4^{\text {th }}$ ed. Brooks/Cole, Belmont, CA.

Pentrák, M., A. Czímerová, J.Madejová, P. Komadel. 2012. Changes in layer charge of clay minerals upon acid treatment as obtained from their interactions with methylene blue. Appl. Clay Sci. 55: 100-107. https://doi.org/10.1016/j.clay.2011.10.012

Pirkarami, A., M. E. Olya. 2017. Removal of dye from industrial wastewater with an emphasis on improving economic efficiency and degradation mechanism. J. Saudi Chem. Soc. 21: S179-S186. https://doi.org/10.1016/j.jscs.2013.12.008

Rahman, M.K., S. Rehman, O.S. B. Al-Amoudi. 2011. Literature Review on Cement Kiln Dust Usage in Soil and Waste Stabilization and Experimental Investigation. IJSER. 7: 77-87.

Reddy T, R., K. S, E. T. S. L. Reddy. 2017. Spectroscopic characterization of bentonite. J. Lasers, Opt. Photonics 4: 171. https://doi.org/10.4172/2469-410x.1000171

Şahin, Ö., M. Kaya, C. Saka. 2015. Plasma-surface modification on bentonite clay to improve the performance of adsorption of methylene blue. Appl. Clay Sci. 116-117: 46-53.

https://doi.org/10.1016/j.clay.2015.08.015

Salem, A., E. Velayi. 2012. Application of hydroxyapatite and cement kiln dust mixture in adsorption of lead ions from aqueous solution, Ind. Eng. Chem. Res. 18: 1216-1222. https://doi.org/10.1016/j.jiec.2011.11.113

Salem, A., H. Afshin, H. Behsaz. 2012. Removal of lead by using Raschig rings manufactured with mixture of cement kiln dust, zeolite and bentonite, J. Hazard. Mater., 223224:13-23. https://doi.org/10.1016/j.jhazmat.2012.01.002

Salem, W.M., W. F. Sayed, S. A. Halawy, R. B. Elamary. 2015. Physicochemical and microbiological characterization of cement kiln dust for potential reuse in wastewater treatment. Ecotoxicol. Environ. Saf. 119: 155161. https://doi.org/10.1016/j.ecoenv.2015.05.012

Salleh, M.A.M., D. K. Mahmoud, W. A. Karim, A. Idris. 2011. Cationic and anionic dye adsorption by agricultural solid wastes: A comprehensive review. Desalination. 280 (1-3):1-13. https://doi.org/10.1016/j.desal.2011.07.019 
Saraya, M.E.S.I., M. E. S. Aboul-Fetouh. 2012. Utilization from cement kiln dust in removal of acid dyes. Am. J. Environ. Sci. 8: 16-24.

https://doi.org/10.3844/ajessp.2012.16.24

Sen, T.K., S. Afroze, H. M. Ang. 2011. Equilibrium, kinetics and mechanism of removal of methylene blue from aqueous solution by adsorption onto pine cone biomass of Pinus radiata. Water. Air. Soil Pollut. 218: 499-515. https://doi.org/10.1007/s11270-010-0663-y

Shehata, N., M. S. Geundi, E. A. El, Ashour, R. M. A. Abobeah. 2016. Structural Characteristics of the Egyptian Clay as a Low-Cost Adsorbent. Int. J. Chem. Process Eng. Res. 3: 35-45.

https://doi.org/10.18488/journal.65/2016.3.2/65.2.35.45

Sikdar, D., K. S. Katti, D. R. Katti. 2008. Molecular interactions alter clay and polymer structure in polymer clay nanocomposites. J Nanosci Nanotechnol. 8 (4): 16381657.

Sun, J., L. Qiao, S. Sun, G. Wang. 2008. Photocatalytic degradation of Orange $\mathrm{G}$ onnitrogen-doped $\mathrm{TiO} 2$ catalysts under visible light and sunlight irradiation, $J$. Hazard.Mater. 155: 312-319.

https://doi.org/10.1016/j.jhazmat.2007.11.062

Tahir, S.S., N. Rauf. 2006. Removal of a cationic dye from aqueous solutions by adsorption onto bentonite clay. Chemosphere. 63: 1842-1848.

https://doi.org/10.1016/j.chemosphere.2005.10.033

Tekin, N., O. Demirbas, M. Alkan. 2005. Adsorption of cationic polyacrylamide onto kaolinite, Micropor. Mesopor.Mater. 85: 340 -350.

https://doi.org/10.1016/j.micromeso.2005.07.004

Toor, M., B. Jin, S. Dai, V. Vimonses. 2015. Activating natural bentonite as a cost-effective adsorbent for removal of Congo-red in wastewater. J. Ind. Eng. Chem. 21: 65366. http://dx.doi.org/10.1016/j.jiec.2014.03.033
Trana, H. N., S. Youb, H. Chaob. 2016. Thermodynamic parameters of cadmium adsorption onto orange peel calculated from various methods: A comparison study, JECE. 4:2671-2682.

https://doi.org/10.1016/j.jece.2016.05.009

Vargas, A.M.M., A. L. Cazetta, A. C. Martins, J. C.G. Moraes, E. E. Garcia, G. F. Gauze, W..F. Costa, V. C. Almeida. 2012. Kinetic and equilibrium studies: Adsorption of food dyes Acid Yellow 6, Acid Yellow 23, and Acid Red 18 on activated carbon from flamboyant pods. Chem. Eng. J. 181-182: 243-250.

https://doi.org/10.1016/j.cej.2011.11.073

Vermohlen, K., H. Lewandowski, H. D.Narres, M. J., Schwuger, 2000, Adsorption of polyelectrolytes onto oxides-the influence of ionic strength, molar mass, and $\mathrm{Ca}^{2+}$ ions. Colloids Surf. A 163: 45-53.

https://doi.org/10.1016/S0927-7757(99)00429-X

Wang, S., E. Ariyanto. 2007. Competitive adsorption of malachite green and $\mathrm{Pb}$ ions on natural zeolite. J. Colloid Interface Sci. 314: 25-31.

https://doi.org/10.1016/j.jcis.2007.05.032

Wong, S., N. A. Ghafar, N. Ngadi, F. A. Razmi, I. M. Inuwa, R. Mat, N. A. S. Amin. 2020. Effective removal of anionic textile dyes using adsorbent synthesized from coffee waste. Sci. Rep. 10: 1-13. https://doi.org/10.1038/s41598020-60021-6

Wu, F.C., R. L. Tseng, R. S. Juang. 2009. Characteristics of Elovich equation used for the analysis of adsorption kinetics in dye-chitosan systems. Chem. Eng. J. 150:366373. http://dx.doi.org/10.1016/j.cej.2009.01.014.

Xue,W., H. He,J. Zhu, P. Yuan, P. 2007. FTIR investigation of CTAB-Al-montmorillonite complexes. Spectrochimica Acta Part A 67:1030-1036.

http://dx.doi.org/10.1016/j.saa.2006.09.024

Yagub, M. T., T. K. Sen, S. Afroze, H. M. Ang. 2014. Dye and its removal from aqueous solution by adsorption: a review. Adv. Colloid Interface Sci. 209: 172-184. https://doi.org/10.1016/j.cis.2014.04.002

Zhu, R.L., L. Z. Zhu, J. X. Zhu, F. Ge, T. Wang. 2009. Sorption of naphthalene and phosphate to the CTMABAl13 intercalated bentonites. J. Hazard. Mater. 168: 15901594. https://doi.org/10.1016/j.jhazmat.2009.03.057 


\section{الملخص العربي}

إزالة صبغة الميثيلين الزرقاء من المحاليل المائية بواسطة معدن البنتونيت والتراب الإسمنتى:

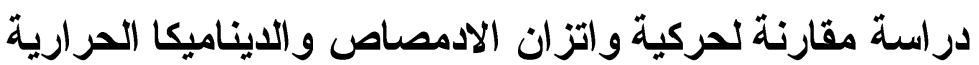

$$
\text { أحمد عبد الخالق الرفاعى }
$$

قامت الدراسة بمقارنة عملية إزالة صبغة الميثلين و الثانية. ووجد تطابق واضح وبشكل جيد لنموذج الدرجة

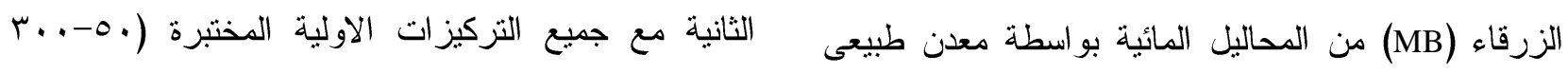

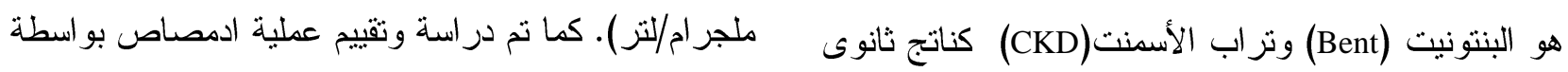

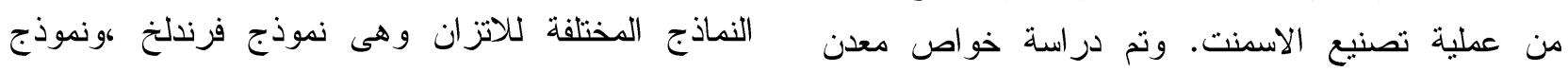

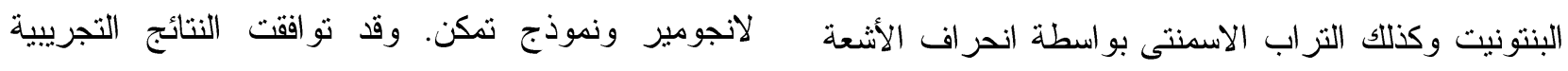

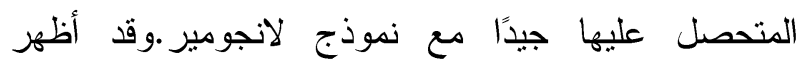

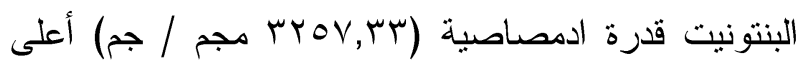

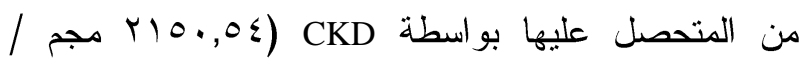
جم). ولوحظ زيادة فى كفائة عملية ازالة صبغة الميثلين

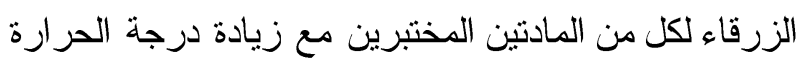

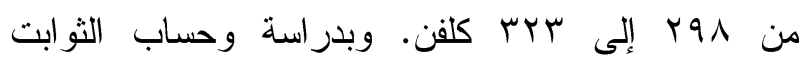
الثيرموديناميكية وجد أن العملية كانت تلقائية و والتفاعل

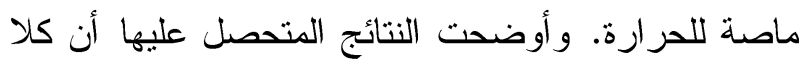

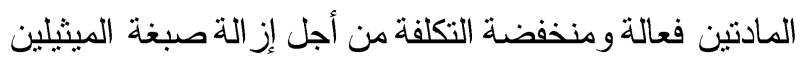

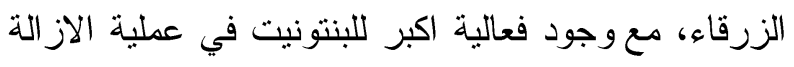
و امتياز لـCKD لـعدم وجود تكلفة. السينية (XRD)، وومضان الأشعة السينية (XRF)، ووكذلك الكئل

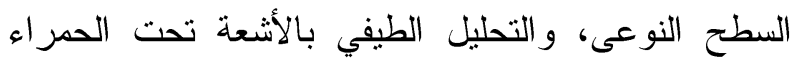
وتحت الميكروسكوب الالكترونى (FTIR) الاختلافات فى الخصائص الفيزيائية والكيميائية. أجريت تجارب الادمصاص على دفعات للمقارنة بين اداء البنتونيت

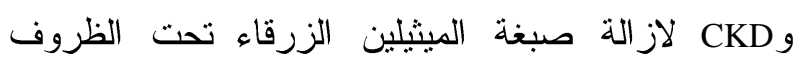
المختلفة من اختلاف التركيز الاولى وكميات المادة المادصة ودرجات ال pH المختلفة وتركيزات الملوحة وكذلك درجات الحرارة المختلفة. كما تم دراسة حركية الادمصاص من خلا النماذج المختلفة وهى نموذج الحركية الاسية، ونموذج Elovich ونموذج الدرجة الاولى الألى 